\title{
Biodegradasi Limbah Cair Tahu Dari Mikroorganisme Indigen Sebagai Bahan Ajar Mikrobiologi Lingkungan Di Perguruan Tinggi
}

\author{
Purwaning Budi Lestari \\ Program Studi Pendidikan Biologi IKIP Budi Utomo \\ Jalan Simpang Arjuno 14b Malang \\ naning_pbl@yahoo.co.id
}

\begin{abstract}
Abstrak: Limbah cair tahu di lokasi penelitian meliputi amilum sebesar 4,032\%, protein 1,415\%, pH 4,35, BOD 352,737 mg/l, dan COD sebesar $474 \mathrm{mg} / \mathrm{l}$, dan jumlahnya melebihi melebihi Nilai Ambang Batas. Tujuan penelitian ini adalah: (1) Mengetahui biodegradasi limbah cair tahu menggunakan bakteri indigen yang potensial mereduksi protein dan karbohidrat, $\mathrm{pH}$ dan BOD serta COD secara in vitro, (2) Mengetahui hasil penelitian tentang biodegradasi limbah cair tahu dari mikroorganisme indigen dapat digunakan sebagai bahan penyusunan bahan ajar Mikrobiologi Lingkungan di Perguruan Tinggi. Rancangan penelitian eksperimen yaitu uji biodegradasi in vitro menggunakan RAK secara Faktorial, dengan perlakuan pertama yaitu variasi jenis isolat dan waktu inkubasi. Eksperimen kedua dengan perlakuan variasi volume starter dan waktu inkubasi yang berpengaruh terhadap uji reduksi amilum dan protein, $\mathrm{pH}, \mathrm{BOD}$, dan $\mathrm{COD}$. Kedua penelitian eksperimen tersebut dianalisis dengan menggunakan Anava Ganda, dilanjutkan uji Duncan Multiple Range Test untuk melihat perbedaan signifikasi variasi uji perlakuan. Hasil penelitian isolat A/F dengan waktu inkubasi 6 hari diperoleh hasil: Protein $(1,206-$ 0,191), Amilum (3,651-1,255), pH (4,35-6,25), BOD (352,737-125,095), COD (474-150). Sedangkan isolat $\mathrm{M}$ diperoleh hasil: protein $(1,189-0,402)$, amilum $(3,488-1,934), \mathrm{pH}(4,35-6,2), \mathrm{BOD}(352,737-$ 216,152), COD (474-186). Volume starter 5\% dan waktu inkubasi 6 hari diperoleh hasil: amilum $(3,46$ $\mathrm{mg} / \mathrm{l}-1,48 \mathrm{mg} / \mathrm{l})$, protein $(1,27 \mathrm{mg} / \mathrm{l}-0,19 \mathrm{mg} / \mathrm{l}), \mathrm{pH}$ (4,35-6,5), BOD (318 mg/l-125 mg/l), COD (450 $\mathrm{mg} / \mathrm{l}-180 \mathrm{mg} / \mathrm{l})$. Kesimpulan hasil penelitian, yaitu: Perlakuan variasi volume starter $5 \%$ dan waktu inkubasi 6 hari, efisien mereduksi amilum, protein, menaikkan pH, menurunkan BOD dan COD. Hasil penelitian digunakan sebagai bahan penyusun bahan ajar mikrobiologi lingkungan di perguruan tinggi.
\end{abstract}

Kata Kunci: Mikroorganisme Indigen, Biodegradasi, Limbah Cair Tahu, Bahan Ajar

\section{Pendahuluan}

Di Indonesia terdapat banyak industri tahu yang dapat dijumpai hampir di setiap daerah. Proses produksi industri tahu dilakukan secara tradisional dan hasil sampingnya berupa limbah. Bahan-bahan organik yang terkandung di dalam air buangan industri tahu pada umumnya sangat tinggi. Karakteristik limbah cair tahu secara fisika meliputi padatan total, suhu, warna dan bau sedangkan secara kimia meliputi bahan organik, bahan anorganik dan gas. Senyawa-senyawa organik di dalam air buangan tersebut berupa protein (40-60\%), karbohidrat (25-60\%), dan lemak (10\%), konsentrasi Chemical Oxygen Demand (COD)
400-1400 ppm, pH 4-5, Biochemical Oxygen Demand (BOD) 3000-4000 mg/L (Wahjono dan Said, 1999).

Limbah organik dari limbah cair tahu yang terdapat di lokasi penelitian meliputi amilum sebesar $4,032 \%$, protein $1,415 \%, \mathrm{pH}$ 4,35, BOD 352,737 mg/l, dan COD sebesar 474 $\mathrm{mg} / \mathrm{l}$. Hal ini masih melebihi Nilai Ambang Batas sesuai Keputusan Gubernur Jawa Timur Nomor 45 Tahun 2002 tentang baku mutu limbah cair untuk industri tahu dan kecap/tempe. Keberadaan limbah cair tahu tersebut berpotensi mengganggu lingkungan sekitar terutama lingkungan perairan. Hal ini harus segera ditanggulangi sebelum limbah tersebut dibuang keperairan. 
Proses biodegradasi oleh bakteri indigen dilakukan melalui reaksi enzimatis yang diekskresi ke luar sel yang dapat mengurai limbah. Bakteri pengurai dalam metabolismenya menghasilkan enzim. Enzim-enzim yang diproduksi bakteri berupa hidrolitik ekstraseluler, yaitu enzim yang diekskresi ke luar sel dan dapat mengurai substrat tertentu. Enzim mempunyai kemampuan unik untuk mempercepat reaksi kimia tanpa ikut terkonsumsi atau berubah setelah reaksi selesai (Madigan, 2003). Polutan dalam limbah akan diurai oleh bakteri sampai volumenya mengecil sehingga dapat mereduksi amilum, protein, menaikkan $\mathrm{pH}$, menurunkan BOD dan COD.

Penelitian ini diharapkan memberikan manfaat bagi dunia pendidikan yaitu sebagai suatu wahana baru khususnya masyarakat akademik di lingkup perguruan tinggi setempat yang tentunya sesuai dengan prinsip-prinsip pengembangan kurikulum (Badan Standart Nasional Pendidikan/BSNP, 2006). Hasil penelitian dimanfaatkan sebagai bahan penyusun bahan ajar bagi pengembangan perkuliahan di perguruan tinggi terutama matakuliah yang terkait dengan mikrobiologi lingkungan.

d. Pengambilan sampel limbah dilakukan dengan tehnik purposive sampling yaitu mengambil sampel disesuaikan dengan kebutuhan pengujian.

e. Rancangan Penelitian

Jenis penelitian merupakan penelitian eksperimen. Penelitian eksperimen pertama menggunakan Rancangan Acak Kelompok (RAK) disusun secara faktoral, terdiri dari 2 faktor yaitu variasi jenis isolat dan waktu inkubasi. Penelitian eksperimen ini menggunakan tiga variabel. Beberapa variabel yang digunakan dalam penelitian ini meliputi: (1) Variabel bebas, yaitu isolat bakteri indigen dengan variasi jenis isolat $\mathrm{A} / \mathrm{F}$, isolat $\mathrm{M}$, dan waktu inkubasi hari ke 0, 2, 4 dan ke 6. (2) Variabel terikat, yaitu kemampuan mereduksi protein dan karbohidrat. (3) Variabel kontrol ialah suhu inkubasi yang digunakan ialah $37^{\circ} \mathrm{C}$, kecepatan shaker ialah $100 \mathrm{rpm}$, umur biakan murni bakteri ialah 1 x 24 jam. Penelitian eksperimen kedua menggunakan Rancangan Acak Kelompok (RAK) disusun secara faktoral, terdiri dari 2 faktor yaitu variasi volume starter isolat dan waktu inkubasi. Parameter pada
Berdasarkan latar belakang yang telah diuraikan di atas, rumusan masalah dalam penelitian ini adalah sebagai berikut: (1) Bagaimana biodegradasi limbah cair tahu menggunakan bakteri indigen yang potensial mereduksi protein dan karbohidrat, $\mathrm{pH}$ dan $\mathrm{BOD}$ serta COD secara in vitro? (2) Bagaimana hasil penelitian tentang biodegradasi limbah cair tahu dari mikroorganisme indigen dapat digunakan sebagai bahan penyusunan bahan ajar Mikrobiologi Lingkungan di Perguruan Tinggi?

\section{Metode}

a. Obyek Penelitian: limbah cair industri tahu di Kelurahan Temas Kecamatan Batu Kota Batu Propinsi Jawa Timur.

b. Populasi: semua mikroorganisme indigen yang terdapat di dalam limbah cair tahu pada industri tahu $3 \mathrm{~S}$ prima di kelurahan Temas kecamatan Batu kota Batu Propinsi Jawa Timur.

c. Sampel: isolat bakteri yang berhasil diisolasi dan memiliki potensi terbesar dalam menguraikan protein, karbohidrat dan lemak dari industri tahu $3 \mathrm{~S}$ prima di Kelurahan Temas Kecamatan Batu Kota Batu. penelitian ini meliputi: uji reduksi karbohidrat, protein, $\mathrm{pH}, \mathrm{BOD}$, dan COD. Penelitian ini dianalisis menggunakan uji $\mathrm{F}$ dengan ANAVA ganda yang diikuti uji Duncan pada sumber variasi yang menunjukkan perbedaan signifikan (Sastrosupadi, 2000).

\section{Hasil}

Penelitian sebelumnya dilokasi yang sama setelah diidentifikasi diperoleh 3 isolat dari limbah cair tahu. Terdiri dari 2 isolat (A dan F) dideterminasi sebagai Bacillus mycoides, isolat M dideterminasi sebagai Bacillus firmus yang digunakan sebagai uji biodegradasi.

\section{Hasil Penelitian dengan Perlakuan Jenis Isolat dan Waktu Inkubasi}

Penelitian ini dilakukan dengan menggunakan variasi jenis isolat bakteri yaitu isolat bakteri $\mathrm{A} / \mathrm{F}$ dan isolat bakteri $\mathrm{M}$, dengan volume starter yang sama yaitu 5\% dan waktu inkubasi 6 hari. Isolat $\mathrm{A} / \mathrm{F}$ dengan waktu inkubasi 6 hari diperoleh hasil: Protein $(1,206-$ $0,191)$, Amilum $(3,651-1,255$, pH $(4,35-6,25)$, BOD (352,737-125,095),COD (474-150). 
Sedangkan isolat $\mathrm{M}$ diperoleh hasil: protein (1,189-0,402, amilum (3,488-1934), $\mathrm{pH}$ (4,356,2), BOD (352,737-216,152), COD (474-186).

Perbedaan kemampuan degradasi secara rinci dapat dilihat pada uji lanjut uji Duncan disajikan pada Tabel1 menunjukkan perlakuan waktu inkubasi (T0, T2, T4, dan T6 hari) memberikan hasil yang berbeda nyata terhadap protein, amilum, $\mathrm{pH}, \mathrm{BOD}$ dan $\mathrm{COD}$ dalam LCT. Waktu inkubasi 6 hari menunjukkan degradasi bahan organik LCT paling potensial.

Tabel.1 Notasi Duncan dari Rerata protein, amilum, pH, BOD dan COD perlakuan waktu inkubasi.

\begin{tabular}{|c|c|c|c|c|c|c|c|c|c|c|}
\hline \multirow{2}{*}{$\begin{array}{l}\text { Waktu } \\
\text { Inkubasi }\end{array}$} & \multicolumn{2}{|l|}{ Protein } & \multicolumn{2}{|l|}{ Amilum } & \multicolumn{2}{|l|}{ pH } & \multicolumn{2}{|l|}{ BOD } & \multicolumn{2}{|l|}{ COD } \\
\hline & Rerata & $\begin{array}{l}\alpha . \\
05\end{array}$ & Rerata & $\begin{array}{l}\alpha . \\
05\end{array}$ & Rerata & $\begin{array}{l}\alpha . \\
05\end{array}$ & Rerata & $\begin{array}{l}\alpha . \\
05\end{array}$ & Rerata & $\begin{array}{l}\alpha . \\
05\end{array}$ \\
\hline T0 & 1.19 & $\mathrm{a}$ & 3.56 & $\mathrm{~d}$ & 4.82 & a & 316.96 & $\mathrm{c}$ & 456.00 & $\mathrm{D}$ \\
\hline T2 & 0.857 & $\mathrm{c}$ & 3.11 & $\mathrm{c}$ & 5.32 & $\mathrm{~b}$ & 298.53 & $\mathrm{c}$ & 372.00 & c \\
\hline T4 & 0,577 & $\mathrm{~b}$ & 2.18 & $\mathrm{~b}$ & 5.77 & $\mathrm{c}$ & 2.29 & $\mathrm{~b}$ & 282.00 & $\mathrm{~b}$ \\
\hline T6 & 0.29 & $\mathrm{a}$ & 1.59 & $\mathrm{a}$ & 6.22 & $\mathrm{~d}$ & 1.70 & $\mathrm{a}$ & 168.00 & $\mathrm{a}$ \\
\hline
\end{tabular}

keterangan:

- $\quad$ Huruf yang menyertai angka dalam tabel menunjukkan notasi Duncan

- Huruf yang sama berarti tidak berbeda nyata

- T: Waktu Inkubasi

- $\quad$ a.05: Tingkat kepercayaan 95\%

\section{Hasil Penelitian dengan Perlakuan Volume Starter dan Waktu Inkubasi}

Hasil penelitian dengan perlakuan volume starter $5 \%$ dan waktu inkubasi 6 hari menunjukkan degradasi bahan organik LCT paling potensial memberikan hasil yang terhadap reduksi protein, amilum, kenaikan $\mathrm{pH}$, Tabel 2 Notasi Duncan dari Rerata Protein, Amilum, pH, BOD dan COD perlakuan Variasi Volume Starter.

\begin{tabular}{llllllllllll}
\hline $\begin{array}{l}\text { volume } \\
\text { starter } \\
\left(\begin{array}{l}\text { \% })\end{array}\right.\end{array}$ & Protein & & Amilum & & pH & & BOD & & COD & \\
& Rerata & A & Rerata & $\alpha$ & Rerata & $\alpha$ & Rerata & $\alpha$ & Rerata & A \\
& & .05 & & .05 & & .05 & & .05 & & .05 \\
5 & 0.67 & a & 2.29 & a & 5.75 & d & 218.32 & a & 295.50 & a \\
2,5 & 0.77 & a & 2.71 & b & 5.16 & c & 252.46 & b & 339.00 & b \\
1 & 0.81 & a & 3.12 & c & 5.16 & b & 290.40 & c & 371.75 & c \\
0 & 1.41 & b & 4.03 & d & 4.35 & a & 352.73 & d & 474.00 & d \\
\hline
\end{tabular}

keterangan:

- Huruf yang menyertai angka dalam tabel menunjukkan notasi Duncan

- Huruf yang sama berarti berbeda tidak nyata

Tabel 2 menunjukkan perlakuan volume starter $0 \%, 1 \%, 2,5 \%$ dan $5 \%$ memberikan hasil yang berbeda terhadap biodegradasi protein dan amilum, pH, BOD dan COD dalam Limbah Cair Tahu. Volume starter 5\% menunjukkan degradasi bahan organik LCT paling potensial. penurunan BOD dan COD dalam Limbah Cair Tahu. Diperoleh hasil: amilum $(3,46 \mathrm{mg} / \mathrm{l}-1,48$ $\mathrm{mg} / \mathrm{l})$, protein $(1,27 \mathrm{mg} / \mathrm{l}-0,19 \mathrm{mg} / \mathrm{l}) \mathrm{pH}(4,35-$ 6,5), BOD (318 mg/l-125 mg/l), COD (450 mg/l - $180 \mathrm{mg} / \mathrm{l})$. Perbedaan kemampuan degradasi secara rinci dapat dilihat pada uji lanjut uji Duncan disajikan pada tabel 2 
Gambar 1. mmenunjukkan bahwa secara umum inokulan bakteri berhasil tumbuh secara eksponensial setelah inkubasi hari ke 0-2, sampai terjadi puncak pada hari 4 sampai fase stasioner, dan menurun pada hari ke-6. Kurva pertumbuhan bakteri ini menggunakan konsorsia
2 spesies yaitu Bacillus mycoides dan Bacillus firmus. Pertumbuhan bakteri mulai series1-4 yaitu volume starter $0 \%-5 \%$, yang mengikuti pola pertumbuhan yang baik adalah seri 4 yaitu volume starter $5 \%$.

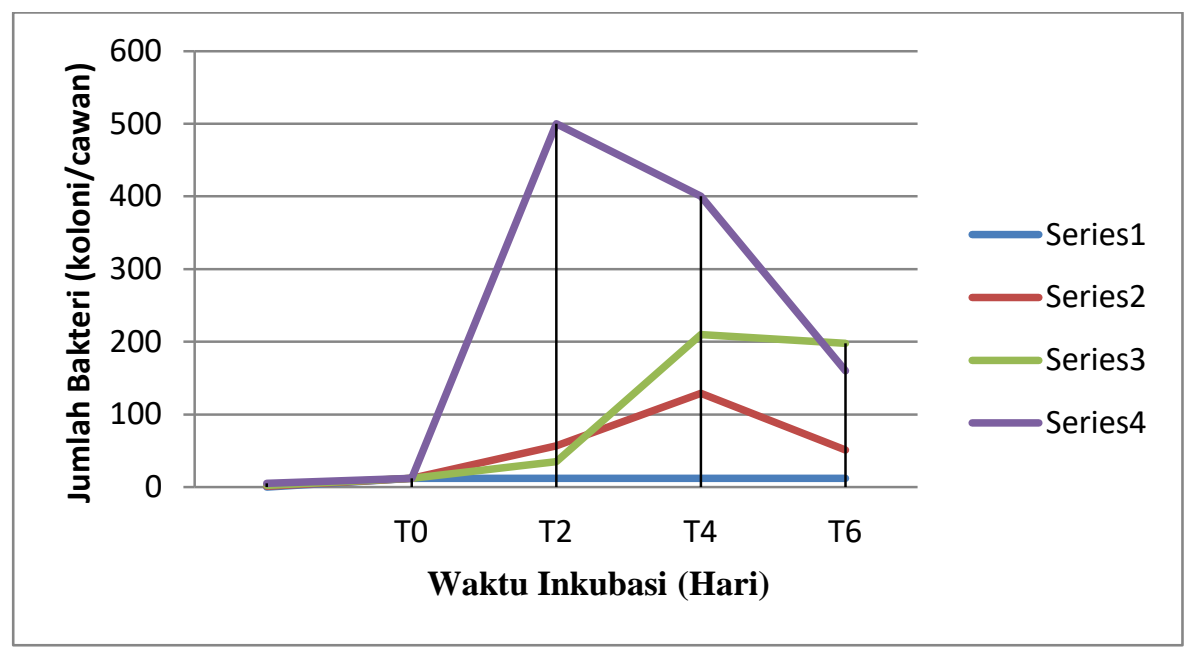

Gambar 1. Kurva Pertumbuhan Bakteri

\section{Keterangan:}

Series 1: volume starter 0\%

Series 2: volume starter 1\%

Series 3: volume starter $2,5 \%$

Series 4: volume starter 5\%

T0 : Waktu inkubasi 0 hari

T2 : Waktu inkubasi 2 hari

T4 : Waktu inkubasi 4 hari

T6 : Waktu inkubasi 6 hari

Tabel 3 menunjukkan perlakuan waktu inkubasi (T0, T2, T4, dan T6 hari) memberikan hasil yang berbeda nyata terhadap protein, amilum, $\mathrm{pH}$, BOD dan COD dalam LCT. Waktu inkubasi 6 hari menunjukkan degradasi bahan organik LCT paling potensial. Hasil uji lanjut dengan uji Duncan untuk variasi waktu inkubasi disajikan pada Tabel 3.

Tabel 3 Notasi Duncan dari Rerata Protein, Amilum, pH, BOD dan COD Perlakuan Variasi Waktu Inkubasi.

\begin{tabular}{llllllllllll}
\hline $\begin{array}{l}\text { Waktu } \\
\text { inkuba } \\
\text { si }\end{array}$ & Protein & & Amilum & & Ph & & BOD & & COD & \\
& Rerata & A & Rerata & A & Rerata & A & Rerata & $\alpha$ & Rerata & A \\
& & .05 & & .05 & & .05 & & .05 & & .05 \\
T0 & 1.33 & C & 3.74 & D & 4.50 & a & 333.76 & d & 460.00 & D \\
T2 & 1.06 & Bc & 3.10 & C & 5.09 & b & 307.75 & c & 420.00 & C \\
T4 & 0.84 & B & 2.77 & B & 5.46 & c & 254.63 & b & 312.00 & B \\
\hline
\end{tabular}




\begin{tabular}{lllllllllll}
\hline T6 & 0.44 & $\mathrm{~A}$ & 2.55 & $\mathrm{~A}$ & 5.73 & $\mathrm{~d}$ & 217.77 & $\mathrm{a}$ & 286.25 & $\mathrm{~A}$ \\
\hline
\end{tabular}

\section{keterangan:}

- Huruf yang menyertai angka dalam tabel menunjukkan notasi Duncan

- Huruf yang sama berarti berbeda tidak nyata

\section{Penyusunan Bahan Ajar}

Biodegradasi limbah cair tahu dari mikroorganisme indigen pada penelitian ini diharapkan dapat digunakan sebagai materi bahan ajar Mikrobiologi lingkungan. Bahan ajar disusun sesuai dengan Prinsip-prinsip dalam penyusunan bahan ajar. Validasi penyusunan bahan ajar dilakukan oleh dua validator

Tabel 4. Hasil Validasi oleh Validator I dan Validator ke II

\begin{tabular}{lc}
\hline \multicolumn{1}{c}{ Aspek Validasi } & Hasil Validasi \\
\hline Kelayakan isi & Valid \\
Kelayakan struktur & Valid \\
Kelayakan bahasa dan penyajian & Valid \\
\hline
\end{tabular}

Hasil validasi penyusunan bahan ajar oleh validator adalah terdapat pada Tabel 5

Tabel 5 Hasil Validasi oleh validator ke II Bahan Ajar

\begin{tabular}{|c|c|}
\hline Tahapan & Hasil \\
\hline $\begin{array}{l}\text { 1. Menentukan SK dan } \\
\text { KD }\end{array}$ & SK dan KD terdapat pada masing-masing bab \\
\hline $\begin{array}{l}\text { 2. Menentukan materi } \\
\text { bahan ajar }\end{array}$ & $\begin{array}{l}\text { Tercakup dalam materi biodegradasi mikroorganisme } \\
\text { indigen }\end{array}$ \\
\hline 3. Standar kebutuhan & $\begin{array}{l}\text { Materi bahan ajar sangat dibutuhkan mahasiswa } \\
\text { biologi terutama pada mata kuliah mikrobiologi }\end{array}$ \\
\hline $\begin{array}{l}\text { 4. Keakuratan materi } \\
\text { ajar }\end{array}$ & Akurat, runtun, dan taat asas \\
\hline 5. Penyusunan draft & Runtun dan taat asas \\
\hline $\begin{array}{l}\text { 6. Kemutakhiran materi } \\
\text { ajar }\end{array}$ & Sesuai, gambar dan pustaka mutakhir \\
\hline $\begin{array}{l}\text { 7. Kesesuaian materi ajar } \\
\text { dengan } \\
\text { mahasiswa }\end{array}$ & $\begin{array}{l}\text { Sesuai dengan perkembangan dan kemampuan } \\
\text { mahasiswa }\end{array}$ \\
\hline 8. Kelayakan judul & Layak sesuai dengan SK dan KD materi kuliah \\
\hline 9. Kelayakan tujuan & Layak sesuai dengan $\mathrm{SK}$ dan tidak sesuai dengan $\mathrm{KD}$ \\
\hline $\begin{array}{l}\text { 10. Kelayakan } \\
\text { pendahuluan }\end{array}$ & Layak sesuai dengan materi \\
\hline $\begin{array}{l}\text { 11. Kelayakan bahan } \\
\text { diskusi }\end{array}$ & Luas \\
\hline 12. Kelayakan pustaka & Mutakhir \\
\hline 13. Standar akurasi & Perbaikan kata pengantar \\
\hline
\end{tabular}



14. Revisi
Perbaikan buku ajar diganti bahan ajar
15. Standar akurasi
Valid (akurat)
16. Produk
Dihasilkan bahan ajar

\section{Keterangan: \\ SK = Standar kompetensi \\ KD = Kompetensi dasar}

Secara umum hasil validasi oleh validator ke II adalah telah valid dan dapat digunakan sebagai bahan ajar pada matakuliah mikrobiologi lingkungan. Hal ini ditunjukkan oleh kebutuhan materi ajar tersebut yang sesuai dengan kurikulum mkrobiologi dipergurauan tinggi. Kelayakan judul, tujuan, pendahuluan, bahan diskusi sudak layak sesuai dengan standar kompetensi dan kompetensi dasar.

Setelah dilakukan revisi oleh validator pada validasi ke I dan ke II, revisi sudah disesuaikan dengan masukan, dan disarankan untuk diperbaiki, setelah direvisi maka validator menyatakan bahwa aspek yang terdapat penyusunan bahan ajar tentang isolasi dan karakterisasi mikroorganisme indigen dari limbah cair tahu yang disusun telah valid dan dapat dipergunakan sebagai bahan ajar untuk menunjang matakuliah mikrobiologi lingkungan di perguruan tinggi.

\section{Pembahasan}

\section{Variasi Jenis Isolat dan Waktu Inkubasi dari Isolat Bakteri Indigen Terhadap biodegradasi Limbah Cair Tahu.}

Berdasarkan temuan penelitian ini maka dapat dijelaskan bahwa selama uji biodegradasi telah terjadi proses penguraian senyawa organik yang terkandung dalam LCT oleh bakteri Bacillus mycoides dan Bacillus firmus. Masingmasing spesies bakteri berperan menguraikan bahan organik yang berbeda sesuai enzim ekstraseluler (eksoenzim) yang dihasilkan. Sumiarsih (2003) mengatakan eksoenzim (enzim ekstraseluler), yaitu enzim yang bekerjanya di luar sel. Umumnya berfungsi untuk mencernakan substrat secara hidrolisis, untuk dijadikan molekul yang lebih sederhana dengan berat molekul $(\mathrm{BM})$ lebih rendah sehingga dapat masuk melewati membrane sel. Energi yang dibebaskan pada reaksi pemecahan substrat di luar sel tidak digunakan dalam proses kehidupan sel. Namun energi tersebut tidak secara langsung digunakan untuk memecah makromolekul menjadi molekul yang lebih sederhana.

Bahan organik LCT merupakan substrat makromolekul, oleh adanya enzim mengalami perubahan menjadi molekul yang lebih sederhana. Proses transformasi bahan organik LCT, akibat pertumbuhan bakteri yang telah diinokulasikan ke dalam LCT dan memiliki kemampuan mendegradasi yang potensial. Hasil penelitian menemukan bahwa penggunaan konsorsia bakteri lebih efektif dibandingkan dengan penggunaan bakteri tunggal terhadap biodegradasi limbah organik. Waluyo, (2009) mengatakan biodegradasi merupakan penguraian atau perombakan secara biologis dan prosesnya berlangsung secara enzimatis. Sistem simbiosis kehidupan antara dua atau lebih bakteri selama proses biodegradasi ternyata dapat menguntungkan dilihat dari segi waktu, hasil, efisiensi dan stabilitas penggunaan bahan baku selama proses dibandingkan dengan sistem tunggal yang hanya menggunakan satu jenis biakan yang berperan dalam proses. Sistem biakan tunggal mikroba dapat mendatangkan kerugian, karena proses berjalan tidak lancar, dan hasil sampingnya akan merugikan pada proses berikutnya. Keuntungannya mudah dikontrol karena hanya berhubungan dengan satu jenis mikroba saja.

\section{Persentase Volume Starter dan Waktu Inkubasi yang Efektif dari Isolat Bakteri Indigen Terhadap Biodegradasi Limbah Cair Tahu (LCT) Secara In Vitro}

Suatu senyawa ditentukan oleh sifat dan susunan bahan, dimana pada umumnya senyawa organik mempunyai sifat cepat terdegradasi dan senyawa anorganik mempunyai sifat lambat terdegradasi. Proses biologis atau mikrobiologis merupakan proses alamiah yang bersifat dinamis dan kontinu selama faktor-faktor yang berhubungan dengan jasad hidup didalamnya terpenuhi. Efektifitas penguraian bahan organik dengan penambahan inokulan bakteri (starter) 
menjadi lebih tinggi jika dibandingkan dengan penguraian bahan tanpa penambahan inokulan (kontrol). Selama biodegradasi berlangsung terjadi transformasi dari senyawa-senyawa yang terkandung dalam LCT. Limbah Cair Tahu di lokasi penelitian meliputi amilum sebesar $4,032 \%$ dan protein $1,415 \%$, sedangkan $\mathrm{pH} 4,35$, BOD 352,737 mg/l, dan COD sebesar $474 \mathrm{mg} / \mathrm{l}$. Bahan organik yang dominan adalah amilum, secara keseluruhan transformasi bahan organik tersebut ditunjukkan oleh kenaikkan $\mathrm{pH}$, penurunan BOD dan COD.

Pada limbah cair tahu terdapat kandungan asam asetat yang merupakan salah satu penyebab $\mathrm{pH}$ limbah cair tahu rendah. Asam asetat tersebut digunakan pada proses pembuatan tahu sebagai koagulan untuk penggumpalan, ( Pohan, 2008). Asam cuka atau asam asetat memiliki rumus empiris $\mathrm{C}_{2} \mathrm{H}_{4} \mathrm{O}_{2}$, rumus ini seringkali ditulis dalam bentuk $\mathrm{CH}_{3-}$ $\mathrm{COOH}, \mathrm{CH}_{3} \mathrm{COOH}$, atau $\mathrm{CH}_{3} \mathrm{CO}_{2} \mathrm{H}$. Molekul asam asetat dalam reaksi glikolisis akan melepaskan satu gugus karboksilnya yang sudah teroksidasi sempurna dan mengandung sedikit energi, yaitu dalam bentuk molekul $\mathbf{C O}_{2}$. Setelah itu, 2 atom karbon yang tersisa dari piruvat akan dioksidasi menjadi asetat (bentuk ionisasi asam asetat). Selanjutnya, asetat akan mendapat transfer elektron dari NAD+ yang tereduksi menjadi NADH. Kemudian, koenzim A (suatu senyawa yang mengandung sulfur yang berasal dari vitamin B) diikat oleh asetat dengan ikatan yang tidak stabil dan membentuk gugus asetil yang sangat reaktif, yaitu asetil koenzimA, yang siap memberikan asetatnya ke dalam siklus Krebs untuk proses oksidasi lebih lanjut. Setiap putaran siklus Krebs, dua karbon masuk dalam bentuk asetat dan dua karbon yang berbeda keluar dalam bentuk $\mathrm{CO}_{2}$ yang teroksidasi sempurna. Asetat bergabung dengan siklus ini melalui penambahan enzimatiknya ke senyawa oksaloasetat yang membentuk sitrat. Kemudian langkah selanjutnya akan menguraikan sitrat kembali menjadi oksaloasetat, yang melepaskan $\mathrm{CO}_{2}$ sebagai buangan.

Aktivitas bakteri asam memungkinkan terjadi kenaikan $\mathrm{pH}$. Proses ini secara prinsip merupakan proses aerobik dimana senyawa organik dioksidasi menjadi $\mathrm{CO}_{2}$ $, \mathrm{H}_{2} \mathrm{O}, \mathrm{NH}_{4}{ }^{+}$dan biomasa baru, karena $\mathrm{NH}^{+}$ akan berikatan dengan air sehingga terbentuk $\mathrm{NH}_{4} \mathrm{OH}$ yang bersifat basa dengan reaksi sebagai berikut.

Enzim bakteri asam

$$
\underset{\text { (asam asetat) }}{\mathrm{C}_{2} \mathrm{H}_{4} \mathrm{O}_{2}} \longrightarrow \mathrm{NH}_{4}^{+}+\mathrm{H}_{2} \mathrm{O}
$$

Judoamijoyo (1990) asam organik dapat digunakan mikroorganisme untuk biosintesis, bila bahan-bahan organik digunakan untuk pertumbuhan bakteri maka $\mathrm{pH}$ cenderung meningkat karena bahan-bahan tersebut akan terdeaminasi. Prescott (2002) deaminasi adalah proses mengkatalisis pemindahan gugus amino $\left(\mathrm{NH}_{2}\right)$ dari asam amino dan molekul lainnya yang mengandung -NH. Selain itu proses deaminisasi menetralisir amin yang menghambat pertumbuhan. Jika mikroba menggunakan sitrat, maka asam akan dihilangkan dari medium biakan, sehingga menyebabkan peningkatan $\mathrm{pH}$.

Secara alamiah bahan organik mudah terurai. Hasil penelitian membuktikan setelah pemberian inokulan bakteri telah terjadi penurunan kadar bahan organik tersebut. Hasil ini merupakan indikasi adanya reduksi bahan organik yang diamati. Biodegradasi bahan organik yang terjadi selama perlakukan adalah meliputi: Biodegradasi amilum dan protein. Kedua isolat mampu mendegradasi bahan organik tersebut, yang berarti mampu menghasilkan enzim amilolitik dan enzim proteolitik. Pertumbuhan bakteri Bacillus mycoides dan Bacillus firmus masing-masing menghasilkan enzim pengurai bahan organik yang dapat mendegradasi bahan organik menjadi substrat yang lebih sederhana. Substrat ini terhidrolisis menjadi asam piruvat, selanjutnya jika cukup oksigen melalui mobilisasi asetilKoA masuk lingkaran asam trikarboksilat (Krebs Cycle) yang akhirnya dibebaskan menjadi $\mathrm{CO}_{2}$ dan $\mathrm{H}_{2} \mathrm{O}$ (Sigit, 2006).

Pada waktu mikroba tumbuh dan berkembangbiak dalam LCT, karbon digunakan untuk menyusun bahan sel-sel mikroba dengan membebaskan karbon dioksida, dan bahanbahan lain yang mudah menguap. Proses biodegradasi ini mikroba turut mengasimilasi nitrogen, fosfor, kalium dan belerang yang terikat didalam protoplasma sel. Tjondronegoro (1997) menyatakan tujuan utama penanganan limbah secara biologi adalah untuk mengoksidasi kadar limbah organik, yaitu 
makanan untuk mikroorganisme. Oksidasi senyawa-senyawa yang mengandung karbon organik menggambarkan mekanisme dimana organisme heterotrofik memperoleh energi untuk sintesis. Konsentrasi limbah turun dengan meningkatnya massa mikroba.

Hasil uji konsorsia paling potensial yaitu konsorsia bakteri Bacillus mycoides dan Bacillus firmus dengan perlakuan volume starter dan waktu inkubasi. Variasi volume starter dan waktu inkubasi berbeda sangat nyata. Volume starter 5\% dan waktu inkubasi 6 hari menunjukkan degradasi bahan organik paling efektif. Hasil penelitian terbukti diperolah kenaikan $\mathrm{pH}$ 49\% (4,35 menjadi 6,5 sedangkan Nilai Ambang Batas/NAB: 6-9), BOD mengalami penurunan $65 \%$ (318 mg/l menjadi $125 \mathrm{mg} / \mathrm{l} \mathrm{NAB} 150 \mathrm{mg} / \mathrm{l})$, dan COD mengalami penurunan $62 \%(450 \mathrm{mg} / \mathrm{l}$ menjadi $180 \mathrm{mg} / \mathrm{l}$ NAB $300 \mathrm{mg} / \mathrm{l})$. limbah organik terjadi penurunan sangat nyata, amilum $63 \%(3,46$ $\mathrm{mg} / \mathrm{l}$ menjadi $1,48 \mathrm{mg} / \mathrm{l})$ dan protein $86 \%(1,27$ $\mathrm{mg} / \mathrm{l}$ menjadi $0,19 \mathrm{mg} / \mathrm{l})$.

Penguraian suatu senyawa tergantung pada konsentrasi dan waktu kontak (Madigan, 2003). Pemberian inokulan bakteri yang diperlakukan kedalam LCT bertujuan memfasilitasi terjadinya interaksi antara bakteri dengan lingkungan limbah. Bakteri akan melakukan aktivitas metabolisme untuk tumbuh dan berkembangbiak, hingga mencapai konsentrasi yang optimum untuk dapat menguraikan senyawa-senyawa organik yang ada dalam LCT. Senyawa organik dapat teroksidasi, oleh karena itu optimasi metabolisme bakteri diperlukan secara aerobik. Sesuai dengan tujuan penelitian untuk dapat mereduksi timbunan bahan organik dalam LCT, maka diusahakan reaksi biotransformasi berlangsung secara optimum yaitu pada perlakuan dikendalikan dengan cara menambah oksigen terus-menerus (diaerasi). Demikian pula upaya waktu kontak antara substrat dengan bakteri penghasil enzim berlangsung baik dan merata, maka diperlakukan pengocokan setiap hari dengan cara menghidupkan shaker pada botol sampel.

Keberhasilan degradasi bahan organik LCT dapat dilihat dari kenaikan $\mathrm{pH}$ dan biodegradasi amilum dan protein serta penurunan BOD dan COD. Adanya perubahan kadar bahan organik LCT menunjukkan bahwa pendegradasi mampu menguraikan bahan organik dalam limbah. Degradasi LCT oleh konsorsia bakteri indigen menghasilkan nilai $\mathrm{pH}$, BOD dan COD memenuhi Nilai Ambang Batas yang dipersyaratkan oleh Keputusan Gubernur Jawa Timur Nomor 45 Tahun 2002. Mencermati waktu inkubasi berkaitan dengan proses pendegradasi LCT bakteri pendegradasi mampu mendegradasi polutan organik secara bertahap dengan mengeluarkan enzim, jika jumlah enzim yang dikeluarkan seimbang dengan volume polutan, maka reduksi total dapat terjadi. Enzim ekstraseluler yang dihasilkan bakteri secara individu berpengaruh kurang berarti terhadap reduksi zat organik, tetapi secara bersama-sama (konsorsia) memberikan hasil yang lebih efektif.

Substrat organik dapat direduksi oleh enzim bakteri jika jumlah biomassa (densitasnya) dalam lingkungan cukup mendukung adanya interaksi antara substrat dan enzim. Penelitian Purwati (1987) memperlihatkan bahwa mikroba campuran lebih baik dalam menurunkan kadar senyawa organik beracun dari limbah cair industri pulp dibandingkan dengan biakan murni Pseudomonas flourescens dan $P$. pyoceaneae. Demikian pula dengan penelitian yang dilakukan Wiryani (1991) yang berhasil menurunkan kadar TSS (Total Suspended Solid), TDS (Total Dissoled Solid), BOD ( Biochemical Oxygen Demand) dan COD (Chemical Oxygen Demand) limbah cair pabrik tempe dengan bantuan mikroba dari kotoran sapi. Hasil penelitian ini menemukan sistem kultur campuran lebih efektif dibandingkan kultur tunggal.

Judoamijoyo (1990) menyebutkan pertumbuhan mikroba biasanya ditentukan oleh waktu yang diperlukan untuk mengadakan massa sel. Waktu penggadaan massa sel dapat berbeda dengan waktu penggandaan jumlah karena massa sel dapat meningkat tanpa penambahan jumlah sel. Tetapi bila dalam suatu lingkungan tertentu interval antara penggandaan sel dan jumlah waktu berlangsung konstan, maka mikroorganisme tumbuh pada laju eksponensial. Pernyataan yang mendukung hasil penelitian tersebut ialah bahwa bakteri memiliki kemampuan pertumbuhan tercepat bila dibandingkan dengan mikroorganisme lainnya. 
Pada beberapa jenis bakteri populasinya dapat mencapai 10-15 milyar sel bakteri per mililiter dalam waktu 24 jam (Pelczar dan Chan, 1988). Bakteri memiliki waktu generasi 20 menit, maksudnya 1 sel bakteri akan membelah diri menjadi 2 sel dalam waktu 20 menit. Jika bakteri berada dalam medium yang menyebabkan terjadinya pembelahan yang optimal, maka dalam waktu 24 jam sel bakteri akan menjadi $2^{27}$ sel. Waktu generasi bakteri selama pertumbuhan aktif bakteri bervariasi sesuai dengan jenisnya (Volk dan Wheeler, 1990). Hal ini sesuai dengan hasil penelitian yang menunjukkan bahwa tiap spesies bakteri hidrolitik mempunyai kemampuan hidrolisis yang berbeda satu sama lain. Hal ini ada kemungkinan disebabkan oleh adanya perbedaan kecepatan biak atau waktu generasi.

Keberadaan 2 macam spesies bakteri hidrolitik ini sangat besar peranannya dalam upaya pemulihan kondisi lingkungan yang tercemar oleh senyawa organik, sebagaimana yang diungkapkan oleh Sheehan (1997) bahwa mikroorganisme memiliki keragaman besar dan tingkat penyebaran yang luas memiliki kapasitas yang tinggi dalam merombak molekul organik. Pemanfaatan mikroorganisme dalam bioremediasi dapat dilakukan melalui dua pendekatan, yaitu melalui pemanfaatan mikroorganisme alamiah yang ada dalam limbah dan penempatan biakan mikroorganisme perombak polutan organik yang sudah diisolasi dan dibiakkan di laboratorium ke dalam lingkungan yang tercemar (Gunalan, 1996). Berdasarkan hal tersebut maka kondisi lingkungan bakteri-bakteri tersebut perlu dijaga agar tetap optimum bagi kehidupan mikroorganisme khususnya bakteri yang bersifat hidrolitik.

Hasil penelitian telah berhasil mengungkapkan bahwa beberapa spesies bakteri indigen yang berasal dari limbah cair tahu industri tahu 3 S Prima di Kelurahan Batu Kota Batu Jawa Timur yang mempunyai kemampuan menghidrolisis amilum dan protein dalam limbah tersebut. Hal ini terbukti berdasarkan hasil penghitungan kadar amilum dan protein yang ternyata menurun setelah diperlakukan dengan spesies-spesies bakteri indigen dengan variasi volume starter dan waktu inkubasi yang berbeda. Sehubungan dengan hal tersebut, maka dapat disarankan agar dilakukan penelitian lebih lanjut dengan memanfaatkan spesies-spesies bakteri indigen yang berasal dari limbah cair industri tersebut dalam upaya melakukan perbaikan lingkungan sekitar dengan teknik bioremediasi.

\section{Implikasi Hasil Penelitian dalam Pembelajaran}

Hasil penelitian ini diimplikasikasikan sebagai bahan ajar pada mata kuliah mikrobiologi lingkungan. Penggunaan bahan ajar yang baik dan berkualitas tersebut diharapkan dapat menunjang keberhasilan belajar mahasiswa. Kebaikan dalam penggunaan buku ajar ini ditandai dengan mudahnya pemahaman informasi yang diberikan dan disusun bersamaan dengan komponenkomponen pembelajaran yang dapat menciptakan kondisi yang diinginkan dalam proses pembelajaran.

Menurut Masduki dan Slamet (2002) tujuan dan manfaat penulisan buku ajar adalah untuk meningkatkan kegiatan belajar mengajar melalui: (1) Pemenuhan kebutuhan penyediaan literatur yang memadai, dan penyampaian materi kuliah lebih terarah sesuai dengan analisis pembelajaran. (2) Memecahkan masalah efisiensi dan efektifitas waktu perkuliahan. (3) meningkatkan kegairahan mahasiswa untuk mempersiapkan diri dalam perkuliahan. Adanya buku ajar diharapkan mampu menggugah kreatifitas dan kerajianan mahasiswa untuk membaca, sehingga dalam perkuliahan komonikasi aktif akan terjadi dua arah antara dosen dan mahasiswa. (4) Memberikan pengetahuan berupa teori, contoh soal dan latihan-latihan, sehingga mahasiswa dapat memahami dan memecahkan masalah yang ada dilapangan.

Biodegradasi mikroorganisme indigen dari limbah cair tahu sebagai sumber belajar pada matakuliah mikrobiologi, khususnya materi mikrobiologi lingkungan. bahan ajar didalamnya terdapat materi-meteri yang berhubungan isolasi bakteri dimana materi tersebut terdapat dalam kurikulum mikrobiologi. harapannya mahasiswa mampu secara langsung membentuk pemahaman, memperoleh keterampilan, memperoleh nilai, mempunyai sikap, dan menemukan solusi terhadap peran bakteri 
indigen dalam limbah cair tahu dalam upaya perbaikan lingkungan perairan dengan teknik bioremediasi.

kaitannya dengan aspek biologi maka materi ajar seharusnya berisi fakta, konsep dan prinsip-prinsip biologi untuk menjawab permasalahan sehari-hari. sehubungan dengan hal tersebut, maka diperlukan suatu pengembangan materi untuk lebih mengembangkan wawasan dan pemahaman mahasiswa terhadap pengetahuan yang diperoleh. pengembangan materi ajar yang dimaksud dalam penelitian ini berupa bahan ajar yang dijadikan sebagai materi ajar bagi mahasiswa agar lebih memahami dan memperoleh informasi tentang biodegradasi mikroorganisme indigen dalam limbah cair tahu. pembelajaran tentang biodegradasi bakteri indigen dapat dilakukan dengan menggunakan materi ajar dimana isi materi teori yang ada hubungannya dengan biodegradasi limbah cair tahu dengan mikroorganisme indigen dari lokasi industri tahu, dan memberikan konsep bagi mahasiswa bahwa setiap lingkungan dengan kondisi/karakter yang dimilikinya memiliki mikroorganisme normal yang hidup indigen. hal ini menanamkan konsep bahwa bakteri indigen benar-benar ada di lingkungan.

mengacu pada kebutuhan dalam proses belajar mengajar sebagaimana yang dijelaskan di atas, maka hasil penelitian ini dapat diterapkan dan dijadikan bahan informasi kepada dosen dan mahasiswa tentang beberapa jenis bakteri indigen yang terdapat dalam limbah cair tahu di industri tahu $3 \mathrm{~s}$ prima, selain itu hasil penelitian ini dapat dijadikan sebagai informasi maupun bahan ajar dalam matakuliah mikrobiologi lingkungan.

\section{Kesimpulan}

Berdasarkan analisis hasil penelitian dan pembahasan dapat disimpulkan sebagai berikut:

1. Potensi konsorsia bakteri yang terdiri dari 2 spesies lebih efektif dibandingkan satu spesies. Hal tersebut ditunjukkan kemampuan konsorsia 2 bakteri paling tinggi mereduksi bahan organik dari parameter $\mathrm{pH}$, BOD, COD dalam waktu 6 hari.

2. Ada perbedaan kemampuan mereduksi protein dan amilum, menaikkan $\mathrm{pH}$ dan menurunkan BOD dan COD dari faktor variasi volume starter dan waktu inkubasi. Starter bakteri 5\% dan waktu inkubasi 6 hari paling efektif menurunkan bahan organik Limbah Cair Tahu, ditunjukkan oleh kenaikkan $\mathrm{pH}$, penurunan BOD dan COD.

3. Hasil penelitian ini dapat digunakan dalam bentuk buku ajar mikrobiologi lingkungan di perguruan tinggi.

\section{Daftar Rujukan}

Anonimus, 2008. Undang-Undang Republik Indonesia Nomor 32 Tahun 2009 Tentang Pengelolaan Lingkungan Hidup.

BNSP, 2006. Badan Standarisasi Nasional Pendidikan. Jakarta: Depdikbud.

Gunalan, 1996. Penerapan Bioremediasi pada Pengolahan Limbah dan Pemulihan Lingkungan Tercemar Hidrokarbon Petroleum. Majalah Sriwijaya Vol. 32 (1): $1-9$

Judoamidjoyo, M., Darwis, A.A. dan Sa'id, E.G., 1990. Teknologi Fermentasi. PAU Bioteknologi. IPB.Jakarta: Rajawali Pers.

Madigan, M.T., Martiko J.M, Paker J. 2003. Brock Biology of Microorganism Tenth Edition. USA. Prentice-Hall Internasional, Inc. 614-642; 669-676; 937-947

Masduki, A. \& Slamet. A. 2002. Buku Ajar Satuan Operasi. Surabaya: FTSP Institut Teknologi Sepuluh Nopember.

Pelczar, M. J dan E. C. S, Chan. 1988. Dasardasar Mikrobiologi Jilid 1 (terjemahan R. S. Hadioetomo). Jakarta: UI Press.

Pohan. N. 2008. Pengolahan Limbah Cair Industri Tahu Dengan Proses Biofilter Aerobik. Tesis tidak diterbitkan. Sumatra: Sekolah Pascasarjana USU Sumatra.(Online) (http://repository.usu.ac.id/bitstream/1 
23456789/4389/1/08E00397.pdf

Diakses 12 Juli 2010)

Purwati, S. \& H. Hardiani. 1987. Pemanfaatan aktivitas mkroorganisme untuk pengolahan air lmbah beracun pada industry pulp. Berita selulosa 23(4): 91-99

Sastrosupadi, A. 2000. Rancangan Percobaan Praktis Bidang Pertanian edisi revisi. Yogyakarta: Penerbit Kanisius

Sheehan, D. 1997. Methods in Biotechnology. Bioremediation Protocols. Totowa. New Jersey: Humana Press.
Sumiarsih, S. 2003. Diklat Kuliah Mikrobiologi Dasar. Yogyakarta: Jurusan Ilmu Tanag Fakultas Pertanian UPN "Veteran" Yogyakarta.

Volk dan Wheeler. 1990. Mikrobiologi Dasar Jilid 1. Jakarta: Penerbit Erlangga.

Waluyo L. 2009. Mikrobiologi Lingkungan. Malang: UMM Press

Wiryani, E. 1991. Analisis kandungan limbah cair pabrik tempe kedelai dan upaya pengolahannya dengan proses anaerobic. Tesis tidak diterbitkan. Bogor: Pasca Sarjana IPB Bogor. 